\title{
Performance of new dairy pastures
}

\author{
A.L.TAYLOR ${ }^{1}$, T.J. FRASER ${ }^{1}$ and W.MCG. $\mathrm{KING}^{2}$ \\ ${ }^{1}$ AgResearch Limited, Lincoln Research Centre, Private Bag 4749, Lincoln, New Zealand \\ ${ }^{2}$ AgResearch Limited, Ruakura Research Centre, Private Bag 3123, Hamilton, New Zealand \\ anna.taylor@agresearch.co.nz
}

\begin{abstract}
It is common practice to renew old and "run-out" pastures that are not performing. Renewing pasture is costly so it is critical that the regrassing pays off.

This trial on ten irrigated dairy farms from North Canterbury to North Otago was initiated to determine the value of regrassing on long term production and persistence of the new pastures. A pasture, deemed as run-out by the farmer, was subdivided and one half was renewed to a novel endophyte ryegrass pasture while the remainder of the paddock remained in the old pasture. The new pasture was compared with the original and another pasture on the same farm, considered by the farmer to be high performing. Pasture composition, production, and quality and pasture pests and endophyte infection have been monitored for two years.

Herbage production is presented for the first 2 years of an ongoing trial, with quality and determination of wild/novel endophyte. When averaged across all 10 farms, the "control", "new" and "good" paddocks have all produced $15 \mathrm{t} \mathrm{DM} / \mathrm{ha}$ in the year to May 2012. Levels of novel endophyte have remained high in the majority of new paddocks over the first 2 years. Clover root weevil is now present on all ten farms, at high levels $\left(>200 / \mathrm{m}^{2}\right)$ in some paddocks.

Production from the new pastures equalled the total DM production from old pastures within 10 months of sowing. However, 2 years following pasture renewal, there has been no production advantage achieved from regrassing a stable old pasture.
\end{abstract}

Keywords: pasture renewal, pasture persistence, irrigated dairy pastures, endophyte, pasture production, pasture composition

\section{Introduction}

Renewing pasture is a costly exercise, so the financial benefit of pasture renewal relies on the high performance and persistence of new pastures.

When renewing a pasture, it is important to identify the reasons why the existing pasture is not performing. The most common reasons include: weed invasion, insect pest damage, environmental impacts, grazing management, and nutrient management (Tozer et al. 2011). This trial aimed to capture these through measurements of soil invertebrate numbers, pasture composition, soil fertility, and management information including fertiliser and irrigation inputs.

The objective was to investigate factors influencing the success of new pasture establishment and subsequent pasture production/composition, and to monitoring endophyte infection and novel endophyte persistence compared to existing pastures.

This trial is being conducted on 10 irrigated dairy farms throughout Canterbury and North Otago. The data presented in this paper is from February 2010 to May 2012.

\section{Methods}

Farmers were identified through existing industry contacts. Each farmer identified a paddock that they intended to renew ("control"), and a high producing paddock ("good"). Farm C had two good paddocks to assess production on both spray and border dyke irrigation paddocks.

On each of the ten farms (Table 1) the control paddock was split in half with one half being renewed ("new") while the remaining half remained in the existing pasture. Direct drilling was used on five farms, while the remaining five used full cultivation to establish their new pastures. All were established from control paddock; therefore the control and new paddocks had the same history.

Two different types of perennial ryegrass were used:

- Diploid seed: 'Samson' AR37, sown at $16 \mathrm{~kg} / \mathrm{ha}$ ryegrass $+3 \mathrm{~kg} / \mathrm{ha}$ 'Tribute' white clover

- Tetraploid seed: 'Halo' AR37, sown at $20 \mathrm{~kg} / \mathrm{ha}$ ryegrass $+3 \mathrm{~kg} / \mathrm{ha}$ 'Tribute' white clover.

Four farms were sown with diploid seed from the same seed line and six farms were sown with tetraploid seed from the same seedline. On eight farms the new paddocks were sown during February-March 2010 (autumn sown) and the remaining during SeptemberOctober 2010 (spring sown).

Management of the control and new paddocks postestablishment was the same for fertiliser applications, grazing management and irrigation applications.

\section{Measurements}

Pasture monitoring and dissections were carried out regularly from the start of the trial on the control and 
good paddocks. New paddocks were sprayed out at this time and then sampled from 6-8 weeks later (first grazing).

Pasture measurements were taken at intervals associated with the current length of grazing rotation. Each paddock contained three cages $(3.3 \mathrm{~m} \times 0.5 \mathrm{~m})$ which were placed in a representative area (approx. 50 $\times 50 \mathrm{~m}$, chosen by visual assessment) of the paddock that would allow a fair comparison with the other treatments. Pasture was cut to grazing height ( $c a$. $35 \mathrm{~mm}$ ) with a rotary lawn mower. Total dry matter ( $\mathrm{kg} \mathrm{DM} / \mathrm{ha}$ ) of the cut herbage was determined by weighing, drying $\left(24 \mathrm{~h}\right.$ at $\left.100^{\circ} \mathrm{C}\right)$ and re-weighing. This was used to determine pasture growth (t DM/ ha). A representative sample of herbage was also taken from within the pasture cage with hand shears (to $c a$. $35 \mathrm{~mm}$ ). This provided proportional composition of plant components (green leaf, legume, weed, sown herbs and dead matter). Cages were shifted to a newly trimmed $(c a .35 \mathrm{~mm})$ area after each harvest.

Pasture insects and ryegrass endophyte levels were monitored annually. In April/May each year, 10 spadesquares were dug from each paddock and grass grub (Costelytra zealandica), porina (Wiseana sp.) clover root weevil (Sitona lepidus) and earthworms were counted. In February/March of each year endophyte presence in ryegrass was determined by immunoblotting (blots) (Simpson et al. 2012), using 50 tillers from different plants in each paddock.

Endophyte strains were identified using genetic analysis. Plant genomic DNA was extracted from a $5-10 \mathrm{~mm}$ long tiller sample using the RED-ExtractN-Amp-Plant PCR kit (Sigma Aldrich). The DNA was analysed via capillary electrophoresis using the appropriate simple sequence repeat (SSR) markers.

Information on the soil type, cultivation history, insect management, cultivars sown in old pastures, fertiliser, effluent and irrigation was collected from farmers (to be reported in future).

\section{Statistical analysis}

An analysis of variance (ANOVA) was used to determine the differences in production that were significant at the $95 \%$ confidence level. The relationships of green grass leaf percentage and legume percentage to paddock type (control, new and good) and year were determined with Kruskal-Wallis one-way ANOVA in GenStat (version 13) to account for the skewness. The weed percentage contained a large proportion of zero values. Consequentially, the probability of observing non-zero values was analysed with a generalised linear model (GLM) assuming group-specific binomial distributions through logit link function. Then, conditional on the probability, the non-zero values were analysed with a linear model assuming normal distributions. The percentage of endophyte present in tillers was analysed with another binomial GLM, and Fisher's exact test. A GLM with negative binomial distributions and log link function was used for worms. For grass grubs, porina and clover root weevil larvae, zero-inflated negative binomial GLMs were used to adjust for zero counts.

\section{Results and Discussion \\ Establishment and Production}

Production during the establishment phase of the autumn sown pastures, from spraying out until July 2010 (approximately 5 months), is shown in Table 2 . The good paddock produced $5.3 \mathrm{t} \mathrm{DM} /$ ha during this time, which was significantly $(\mathrm{P}<0.05)$ greater than the new paddock, but not the control paddock.

The North Canterbury farms were not sown until September/October 2010. Production from the time of spraying out until July 2011 (approximately 10 months) for the new paddocks on these two spring farms is shown in Table 2. During this time the good paddock out-produced both the control and new paddocks $(\mathrm{P}<0.05)$.

In both establishment seasons the control and new paddocks did not differ significantly in production. This indicates that at the end of this establishment time

Table 1. Farms locations and establishment details

\begin{tabular}{lcccc}
\hline Farm & Region & Sown & Method & Seed type \\
\hline A & North Otago & Autumn & Direct-drilled & Tetraploid \\
B & North Otago & Autumn & Direct-drilled & Tetraploid \\
C & North Otago & Autumn & Direct-drilled & Diploid \\
D & South Canterbury & Autumn & Cultivated & Diploid \\
E & Mid Canterbury & Autumn & Cultivated & Diploid \\
F & Mid Canterbury & Autumn & Cultivated & Tetraploid \\
G & Central Canterbury & Autumn & Cultivated & Tetraploid \\
H & Central Canterbury & Autumn & Direct-drilled & Tetraploid \\
I & North Canterbury & Spring & Cultivated & Tetraploid \\
J & North Canterbury & Spring & Direct-drilled & Tetraploid \\
\hline
\end{tabular}


period ( 5 months for autumn sown and 10 months for spring sown) the loss of production from renewing a pasture during re-establishment was compensated by better subsequent growth.

From August 2010 to July 2011, the good and new paddocks both produced more than the control paddock but the difference was not significant (Table 2 ), therefore there was no production gain to regrassing in this year.

During August 2011 to May 2012 (all farms), there was no difference in production between the control, new or good paddocks (ca.15 t DM/ha). Interestingly, the good paddocks on several farms had lower dry matter production in this year, than the control paddocks. This raises the question of what measurement the farmer used to identify, not only the good paddock but also the control paddock, judged as needing to be renewed.

While the new pastures grew faster than old paddocks in the first 10 months, the more rapid growth was only enough to compensate for the down time created by renewing the pasture. By the following year there was no advantage in dry matter production in the new paddocks.

\section{Pasture Composition}

In the 2010/2011 season there was no difference in the percentage of green grass leaf present in the control, new and good paddocks, but the good and control paddocks had significantly more legume than the new paddocks $(\mathrm{P}<0.05)$ (Table 3$)$.

In the $2011 / 2012$ season, the control paddocks had a significantly greater weed component, while the weed component in new paddocks was least. The green grass leaf component in the new paddocks was highest, but significantly greater than only the good paddocks. The good paddocks had a larger percentage of legumes than the new and control paddocks. This suggests a link between farmers' observation of a paddock being a top performer and the amount of clover present. The legume percentage throughout the year and across individual paddocks ranged from $0-45 \%$; clover was present at an overall average of only $8 \%$. This is lower than the $10-20 \%$ clover content that used to be considered "normal" in New Zealand dairy pastures (Harris et al. 1997; Caradus et al. 1996). It is also considerably lower than the clover content (30-50\%) recommended for having an impact on the pastures' nitrogen economy and animal performance (Caradus et al. 1996).

There was no change in weed composition in the control paddocks between the 2010/11 and 2011/12 years (statistics not shown), but the green grass leaf percentage increased $(\mathrm{P}<0.05)$ while the legume component decreased $(\mathrm{P}<0.05)$ in the latter year. The good paddocks' weed composition increased in 2011/12 but there was no change in the green grass leaf and legume compositions. In the new paddocks the weed component decreased, while there was no change in green leaf or legume content. Although the new paddocks had, in general, fewer weeds they also had less clover. This suggests that overall pasture quality has not been improved by pasture renewal. In observation and discussion with farmers there appears

Table 2. Establishment and production of control, new and good paddocks.

\begin{tabular}{lcccc}
\hline Paddock ID & $\begin{array}{c}\text { Establishment to } \\
\text { Jul 2010 } \\
\text { Autumn sown }\end{array}$ & $\begin{array}{c}\text { Establishment to } \\
\text { Jul 2011 } \\
\text { Spring sown }\end{array}$ & $\begin{array}{c}\text { Total from } \\
\text { Aug 2010 to Jul 2011 } \\
\text { Autumn sown }\end{array}$ & $\begin{array}{c}\text { Total From } \\
\text { Aug 2011 to May 2012 } \\
\text { All farms }\end{array}$ \\
\hline Control & & Pasture growth (t DM/ha.) & \\
New & $4.5^{\text {ab }}$ & $15.1^{\mathrm{b}}$ & 15.7 & 15.4 \\
Good & $3.9^{\mathrm{b}}$ & $15.0^{\mathrm{b}}$ & 16.3 & 15.6 \\
\hline
\end{tabular}

Note: There is still a winter cut in early August to bring the 2011/2012 year to an annual total. Means with superscript letters in common are not significantly different; $\mathrm{P}<0.05$.

Table 3. Proportional composition of plant components in the $2010 / 2011$ and $2011 / 2012$ seasons.

\begin{tabular}{lcccccc}
\hline & \multicolumn{2}{c}{ Green Grass Leaf } & \multicolumn{2}{c}{ Pasture composition (\%) } & \multicolumn{2}{c}{ Weed } \\
Paddock ID & $2010 / 2011$ & $2011 / 2012$ & $2010 / 2011$ & $2011 / 2012$ & $2010 / 2011$ & $2011 / 2012$ \\
\hline Control & 82.0 & $85.6^{\mathrm{ab}}$ & $8.9^{\mathrm{a}}$ & $5.6^{\mathrm{b}}$ & 5.2 & $5.6^{\mathrm{a}}$ \\
New & 84.9 & $86.0^{\mathrm{a}}$ & $6.4^{\mathrm{b}}$ & $6.5^{\mathrm{b}}$ & 4.0 & $2.7^{\mathrm{c}}$ \\
Good & 83.1 & $83.4^{\mathrm{b}}$ & $10.5^{\mathrm{a}}$ & $8.4^{\mathrm{a}}$ & 3.3 & $4.2^{\mathrm{b}}$ \\
\hline
\end{tabular}

Note: Within a column, means with superscript letters in common are not significantly different; $P<0.05$. Where letters are missing, there was no significant difference. 
to be a link between farmer's observation as a paddock being a top performer and the amount of clover present.

\section{Endophyte}

Endophyte infection frequency remained high in the majority of new paddocks over the first 2 years, with the exception of farm D, where it decreased (Table 4). No chemicals were used in the establishment of new pasture (cultivated) on farm D, therefore it is likely that some of the original low endophyte pasture remained. The farm $\mathrm{H}$ new paddock endophyte infection frequency has also significantly decreased from the first year of sampling.

When comparing the endophyte presence between the control, new and good paddocks (Table 4) in all years, the new paddocks had the greatest percent of positive blots and the control paddocks had the least.

Of the endophyte present, the majority of new

Table 4. Percentage of ryegrass tillers with endophyte present.

\begin{tabular}{|c|c|c|c|c|}
\hline \multirow[b]{2}{*}{ Farm } & \multicolumn{4}{|c|}{ Percent of Ryegrass tillers with endophyte present } \\
\hline & Paddock ID & Apr 2010 & Mar 2011 & Feb 2012 \\
\hline \multirow[t]{3}{*}{ A } & Control & 68 & 46 & 52 \\
\hline & New & 88 & 86 & 86 \\
\hline & Good & 12 & 18 & 28 \\
\hline \multirow[t]{3}{*}{$\mathrm{B}$} & Control & 32 & 2 & 0 \\
\hline & New & $76^{b}$ & $82^{b}$ & $100^{a}$ \\
\hline & Good & 0 & 6 & 4 \\
\hline \multirow[t]{4}{*}{ C } & Control & 100 & 94 & 98 \\
\hline & New & 70 & 72 & 70 \\
\hline & Good & 90 & 60 & 66 \\
\hline & Good & 96 & 76 & 92 \\
\hline \multirow[t]{3}{*}{$D$} & Control & 6 & 0 & 0 \\
\hline & New & $70^{a}$ & $36^{b}$ & $48^{a b}$ \\
\hline & Good & 10 & 14 & 38 \\
\hline \multirow[t]{3}{*}{$E$} & Control & 38 & 42 & 30 \\
\hline & New & 70 & 56 & 58 \\
\hline & Good & 100 & 96 & 72 \\
\hline \multirow[t]{3}{*}{$F$} & Control & 10 & 6 & 8 \\
\hline & New & 92 & 94 & 92 \\
\hline & Good & 76 & 90 & 80 \\
\hline \multirow[t]{3}{*}{$G$} & Control & 8 & 10 & 4 \\
\hline & New & 76 & 88 & 86 \\
\hline & Good & 88 & 84 & 52 \\
\hline \multirow[t]{3}{*}{$\mathrm{H}$} & Control & 100 & 94 & 98 \\
\hline & New & $98^{a}$ & $60^{\mathrm{b}}$ & $68^{b}$ \\
\hline & Good & 100 & 94 & 92 \\
\hline \multirow[t]{3}{*}{1} & Control & & 94 & 82 \\
\hline & New & & $90^{\mathrm{a}}$ & $64^{b}$ \\
\hline & Good & & 84 & 66 \\
\hline \multirow[t]{3}{*}{$J$} & Control & & 94 & 92 \\
\hline & New & & 78 & 76 \\
\hline & Good & & 76 & 62 \\
\hline \multirow[t]{3}{*}{ Average of all farms } & Control & $45^{c}$ & $48^{c}$ & $46^{c}$ \\
\hline & New & $80^{a}$ & $74^{\mathrm{a}}$ & $75^{a}$ \\
\hline & Good & $64^{b}$ & $63^{b}$ & $59^{b}$ \\
\hline
\end{tabular}

Note: Within a row for new paddocks only, means with superscript letters in common are not significantly different; $\mathrm{P}<0.05$. Where letters are missing for new paddocks, there was no significant difference. For average of all farms, where superscript letters are common within columns, values are not significantly different $(P<0.05)$. 
paddocks maintained $100 \%$ of the sown endophyte (AR37) (Table 5). Only one paddock (farm H) had a significant amount of other endophyte. This was a direct-drilled paddock where the kill of existing vegetation was only partially successful, so it is likely that this is remnant pasture from the previously sown ryegrass cultivar.

Table 5 shows the results from endophyte

Table 5. Percentage of sown endophyte (of total endophyte present) in ryegrass tillers taken in March 2012 from new paddocks.

\begin{tabular}{lcc}
\hline & \multicolumn{2}{c}{ Endophyte type (\%) } \\
Farm & Sown & Other \\
\hline A & 97 & 3 \\
B & 100 & \\
C & 93 & 5 \\
D & 100 & \\
E & 100 & \\
F & 100 & \\
G & 100 & \\
H & 67 & \\
I & 100 & \\
J & 100 & \\
\hline
\end{tabular}

identification through genetic analysis in the new paddocks. There appeared to be almost no regeneration from the old ryegrass pastures. This may be a result of the good grazing management practices on irrigated dairy farms which prevented seed head emergence.

\section{Soil invertebrates}

There was no significant difference in average worm numbers between the control, new and good paddocks at the first sampling in 2010 (see Table 6). However, in subsequent years the good paddocks had a lower number of worms overall. Grass grub numbers were higher in the good paddocks and lower in the control paddocks in the first sampling. This ranking did not show the same trend in subsequent years. Grass grub numbers in all averaged paddock types had a range of $4-71 / \mathrm{m}^{2}$, below that considered a damaging population for a newly sown ryegrass/white clover pasture (above ca. $\left.75 / \mathrm{m}^{2}\right)$ (East et al. 1982; Bell et al. 2009).

At the start of this trial clover root weevil (CRW) was not present at any of the trial sites. By the end of the first year, however, larvae were found on eight of the ten farms and by the second year were present on all farms. CRW numbers significantly $(\mathrm{P}<0.001)$ increased each year in all paddocks.

In 2010 sampling took place in April, several months

Table 6 Invertebrate numbers/m² for control, new and good paddocks for 2010, 2011 and 2012.

\begin{tabular}{|c|c|c|c|c|c|}
\hline \multirow[b]{2}{*}{ Year } & \multirow[b]{2}{*}{ Paddock ID } & \multicolumn{4}{|c|}{ Invertebrate numbers $\left(/ m^{2}\right)$} \\
\hline & & Earthworm & Grass grubs & Porina & CRW \\
\hline \multirow[t]{3}{*}{2010} & Control & 493 & 27 & 1 & 0 \\
\hline & New & 466 & 31 & 0 & 0 \\
\hline & Good & 455 & 71 & 5 & 0 \\
\hline \multirow[t]{3}{*}{2011} & Control & 647 & 15 & 4 & 30 \\
\hline & New & 589 & 4 & 4 & 23 \\
\hline & Good & 439 & 8 & 3 & 23 \\
\hline \multirow[t]{3}{*}{2012} & Control & 542 & 21 & 6 & 111 \\
\hline & New & 436 & 8 & 9 & 87 \\
\hline & Good & 383 & 24 & 7 & 74 \\
\hline
\end{tabular}

Note: $\mathrm{CRW}=$ clover root weevil

Table 7 Invertebrate numbers $/ \mathrm{m}^{2}$ for cultivated and direct-drilled sowing methods for 2010, 2011 and 2012.

\begin{tabular}{|c|c|c|c|c|c|}
\hline \multirow[b]{2}{*}{ Year } & \multirow[b]{2}{*}{ Establishment method } & \multicolumn{4}{|c|}{ Invertebrate numbers $\left(/ \mathrm{m}^{2}\right)$} \\
\hline & & Earthworm & Grass grubs & Porina & CRW \\
\hline \multirow[t]{2}{*}{2010} & Cultivated & 308 & 43 & 0 & 0 \\
\hline & Direct-drilled & 693 & 15 & 0 & 0 \\
\hline \multirow[t]{2}{*}{2011} & Cultivated & 525 & 4 & 5 & 14 \\
\hline & Direct-drilled & 654 & 4 & 2 & 32 \\
\hline \multirow[t]{2}{*}{2012} & Cultivated & 417 & 8 & 13 & 106 \\
\hline & Direct-drilled & 455 & 8 & 5 & 68 \\
\hline
\end{tabular}


after sowing of the new paddocks. During the pasture renewal process, grass grub numbers are expected to be diminished and then an increase is expected until a peak at around year 2-3 as populations of this pest re-establish (Watson et al. 2000; Bell et al. 2009). However, this trend was not evident in this trial, nor was there significant differences in numbers between sowing methods (see Table 7).

Direct-drilled paddocks had a significantly larger number of earthworms than cultivated paddocks (693 cf. 308 earthworms $\left./ \mathrm{m}^{2} ; \mathrm{P}<0.01\right)$. By the time of the 2011 sampling this difference was no longer significant. In this trial all new paddocks were renewed from grass to grass in a short timeframe. Some paddocks were sprayed, cultivated and sown within a week. This may have allowed for the survival of grass grubs during the renewal process, explaining why a reduction in numbers in the cultivated paddocks compared with direct-drilled paddocks was not seen. Also, the number of grass grubs present in the new paddocks before sowing was not measured, so it is possible that cultivating did reduce the pre-sowing grass grub numbers more than directdrilling, but without those measurement this cannot be confirmed. Grass grub numbers were very low in all paddocks in 2011 and 2012.Overall porina numbers were very low, with no paddock exceeding $18 / \mathrm{m}^{2}$, well below the threshold of $50 / \mathrm{m}^{2}$ thought to reduce pasture production (Agriseeds 2012).

In addition to the invertebrates mentioned above, the following species were also present in low numbers $\left(<2 / \mathrm{m}^{2}\right)$ : mealybug (Balanococcus poae), soldier fly (Inopus rubriceps), wireworms (Elateridae), slugs (Derocera reticlatum), Tasmanian grass grub (Aphodius tasmaniae), two unidentified beetle (Coleoptera) species and two unidentified moth/butterfly (Lepidoptera) species.

\section{Conclusion}

Establishing new ryegrass based pasture on dairy farms has not resulted in increased dry matter production.

New pastures produced enough extra growth to equal the total DM production from old established pastures within 10 months. However they did not exceed the total dry matter production of the old pastures, either paddocks judged "run-out" or "good" by farmers.

Although individual paddocks did have considerable amounts of clover, the overall average clover content of the pasture in this trial was only $8 \%$. The new paddocks on average had the least amount of clover in the pasture, but also the least amount of weeds. New pastures have so far maintained high populations of the new ryegrass with novel endophyte. Grass grub and porina numbers were low on all farms. However CRW is now present on all farms with their numbers increasing over three years. The measurements discussed above are continuing, to assess long term trends.

\section{ACKNOWLEDGEMENTS}

The authors thank the owners, sharemilkers and managers of the 10 farms this trial was conducted on; their continued support and cooperation is imperative to this project. We also thank Westlea Clarke-Hill and Trevor Knight for help with data collection and Chikako van Koten for statistical analysis. This project is funded by dairy farmer levies through DairyNZ as part of the Dairy pastures for persistence and production: best practice renewal project.

\section{REFERENCES}

Agriseeds 2012. Porina. Accessed 15 August 2012. http://www.agriseeds.co.nz/downloads/Pasture $\% 20$ pests\%20-\%20porina\%202012.pdf

Bell, N.L.; King, W.McG.; Rennie, G.M.; Yates, L.J.; Wilson, D.J.; Howlett, S.A.; Trolove, M.R. 2009. Best-practice pasture renewal for forage production and sustainability: description of a farmer-led study and initial findings. Proceedings of the New Zealand Grassland Association 71: 155-159.

Caradus, J.R.; Harris, S.L.; Johnson, R.J. 1996. Increased clover content for increased milk production. Proceedings of the Ruakura Farmers' Conference 48: 42-49.

East, R.; Koller, M.S.; Willoughby, B.E. 1982. Effects of grass grub density on production of tall fescue, cocksfoot and ryegrass sown with white clover. Pp. 82-85. In: Proceedings of the 35th New Zealand Weed and Pest Control Conference.

Harris, S.L.; Clark, D.A.; Auldist, M.J.; Waugh, C.D.; Laboyrie, P.G. 1997. Optimum white clover content for dairy pastures. Proceedings of the New Zealand Grassland Association 59: 29-33.

Simpson, W.R.; Schmid, J.; Singh, J.; Faville, M.J.; Johnson, R.D. 2012. A morphological change in the fungal symbiont Neotyphodium lolii induces dwarfing in its host plant Lolium perenne. Fungal Biology 116: 234-240.

Tozer, K.N.; Cameron, C.A.; Thom, E.R. 2011. Weed ingress and pasture persistence in Bay of Plenty dairy farm: field observations and farmer perceptions. New Zealand Plant Protection 64: 68-74.

Watson, R.N.; Bell N.L.; Neville, F.J.; Davis, L.T. 2000. Pest populations during the first six years in ryegrass pastures containing white or Caucasian clover. New Zealand Plant Protection 53: 410-414. 